Original Research Paper

\title{
Rumah Pangan Lestari Sebagai Solusi Peningkatan Pendapatan Keluarga
}

\author{
Yusri Ainun $^{1^{*}}$, Agil Al Idrus ${ }^{2}$ \\ ${ }^{1}$ Program Studi Pendidikan Matematika, Fakultas Keguruan dan Ilmu Pendidikan, Universitas Mataram, Mataram, Indonesia \\ ${ }^{2}$ Program Studi Pendidikan Biologi, Fakultas Keguruan dan Ilmu Pendidikan, Universitas Mataram, Mataram, Indonesia
}

DOI: https://doi.org/10.29303/jpmpi.v3i2.585

Sitasi:. Yusri, A,., \& Idrus, A. A. (2020). Rumah Pangan Lestari Sebagai Solusi Peningkatan Pendapatan Keluarga. Jurnal Pengabdian Magister Pendidikan IPA, 3(2)

Article history

Received: 25 Oktober

Revised: 15 Nopember

Accepted: 29 Desember

*Corresponding Author: Yusri

Ainun, Program Studi

Pendidikan Matematika,

Fakultas Keguruan dan Ilmu

Pendidikan, Universitas

Mataram, Mataram, Indonesia

Email:

yusriainun2@gmail.com

\begin{abstract}
Kondisi Pandemi Covid-19 yang saat ini masih terjadi di Indonesia, tentunya membawa dampak yang cukup signifikan kepada warga Indonesia, baik dari segi kesehatan maupun perekonomian. Kondisi saat ini yang masih mengharuskan masyarakat untuk tetap berada di rumah, belajar maupun bekerja dari rumah walaupun beberapa dari sebagian masyarakat telah menjalankan aktivitas/rutinitas seperti biasa atau yang disebut dengan istilah "New Normal". Akibatnya, banyak masyarakat yang hanya berdiam di rumah tanpa adanya perkerjaan yang dapat dikerjakan yang dapat membantu kebutuhan keluarga. Bukan hanya itu, tingkat angkatan kerja di Rabadompu Barat masih tergolong rendah karena masih banyak yang berpenghasilannya rendah. Oleh karena itu, untuk mengisi waktu luang keluarga yang sedang menjalankan isolasi di rumah, pada kegiatan KKN Terpadu Era new Normal ini kami mengadakan program Rumah Pangan Lestari (RPL). Rumah Pangan Lestari (RPL) merupakan program yang dapat dilakukan masyarakat Rabadompu Barat ditengah pandemi saat ini, yang dapat menambah ataupun meningkatkan ketahanan pangan keluarga sehingga perekonomiannya tidak menurun. Pada program RPL ini, masyarakat diajak untuk menanam seperti sayur - sayuran dan lainnya yang dapat dijual, sehingga meningkatkan pendapatan keluarga. Penggunaan ruang yang tersedia walaupun dalam luasan yang kecil akan mampu menyediakan pangan yang bernilai gizi dalam jumlah yang cukup. Model kegiatan yang dilakukan meliputi kegiatan pendidikan seperti sosialisasi dan demplot sreta pelatihan dalam menanam. Hasil kegiatan ini memberikan dampak posistif terhadap perubahan perilaku masyarakat. Lahan kosong disekitar rumah dan sepanjang kiri kanan jalan yang selama ini tidak dimanfaatkan, dapat dimanfaatkan sebagai kawasan yang menunjang ekonomi masyarakat. Pendapatan keluarga yang diperoleh masing-masing rumah tangga meningkat serta ibu - ibu yang menganggur di rumah dapat menjual hasil yang ditanam. Pendapatan keluarga yang diperoleh cukup besar untuk kebutuhan sehari - hari keluarga. Lingkungan yang dulu terkesan gersang kini berubah menjadi sejuk dan dan asri.
\end{abstract}

Keywords: Rumah pangan lestari; Pendapatan keluarga dengan pandemi yang melanda seluruh dunia tidak terkecuali Indonesia. Sehingga kebutuhan pangan

di Indonesia menurun begitupun di desa Kelurahan Rabadompu Barat. Oleh karena itu, dengan adanya program Rumah Pangan Lestari (RPL), kebutuhan ekonomi dan pangan di Rabadompu Barat dapat meningkat.
Raba, Kota Bima merupakan salah satu desa yang penduduknya masih banyak yang bermata pencaharian sebagai buruh tani, petani disebabkan kualitas angkatan kerja yang rendah. Ditambah 
Rumah Pangan Lestari adalah rumah yang memanfaatkan pekarangan secara intensif melalui pengelolaan sumberdaya alam lokal secara bijaksana, yang menjamin kesinambungan persedian bahan pangan dengan tetap memelihara dan meningkatkan kualitas, termasuk tata nilai dan keanekaragaman (Balitbangtan, 2011).

Di Rabadompu Barat program ini telah dilaksanakan yaitu memanfaatkan lahan pekarangan dengan cara ditanami tanaman untuk kebutuhan sehari-hari, namun kegiatannya masih bersifat sambilan untuk mengisi waktu luang. Kegiatan ini apabila dikelola dengan baik akan memberikan nilai tambah berupa kecukupan gizi dan berpeluang meningkatkan penghasilan rumah tangga.

Pola Pertanian dengan model Rumah Pangan Lestari (RPL) merupakan salah satu model pertanian yang dikembangkan pada lahan terbatas untuk menghasilkan produk pangan. Produksi ini berkaitan dengan pemenuhan kebutuhan pangan, kenyamanan hidup ditengah-tengah pandemi di wilayah perkotaan dan menambah nilai estetika. Konsep pengembangannya, setiap rumah ditanami berbagai jenis tanaman hortikultura (sayuran, aneka bunga dan buah-buahan) termasuk tanaman biofarmaka. Fungsi lain dari kegiatan ini adalah sebagai jasa lingkungan (ecologycal service) juga untuk menambah lahan pertanian.

\section{Metode}

\section{a. Persiapan}

Pada tahap persiapan setelah mendapatkan pembekalan dan pelepasan dari pihak kampus, kami memohon izin kepada pihak desa khususnya kepada lurah Rabadompu Barat untuk melaksanakan kegiatan KKN Terpadu dengan tema Rumah Pangan Lestari (RPL). Setelah mendapatkan izin dan rekomendasi mitra dari pihak desa, kami mengajukan kerja sama dengan pihak mitra yaitu desa Rabasompu Barat.

Persiapan yang dilakukan yaitu menentukan lokasi yang akan dijadikan sebagai tempat untuk melaksanakan kegiatan tersebut. Kemudian melakukan survei lokasi yang sekiranya dapat menjadi lokasi yang yang tepat.
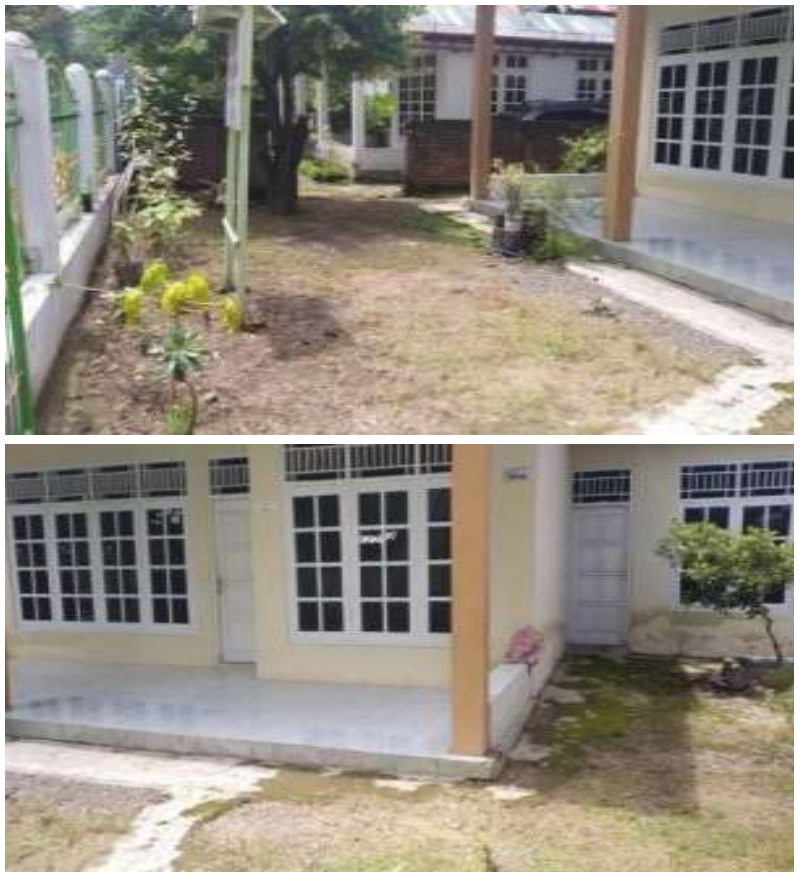

Gambar 1. Survei Lahan

\section{b. Konsultasi dengan Mitra}

Kegiatan ini bertujuan untuk memberdayakan kelompok ibu-ibu rumah tangga yang tidak bekerja yang tergabung dalam PKK untuk pemanfaatan pekarangan sebagai usaha sampingan yang dapat meningkatkan pendapatan keluarga.

\section{c. Sosialisasi dan Demonstrasi Plot}

Sosialisasi disampaikan dengan maksud dan tujuan sesuai rencana/persiapan pelaksanaan kegiatan. Kegiatan ini juga dilaksanakan di tempat yang telah ditentukan dihadiri oleh tim pelaksana serta masyarakat lainnya dengan harapan dapat mendorong kreativitas mereka di bidang ekonomi kreatif. Kegiatan ini juga mempunyai prospek yang baik untuk pendapatan keluarga. demonstrasi dilakukan untuk memberikan pemahaman secara langsung kepada masyarakat seperti demostransi pemanfaatan lahan pekarangan rumah ataupun lahan kosong yang dapat digunakan di sekitar rumah. 


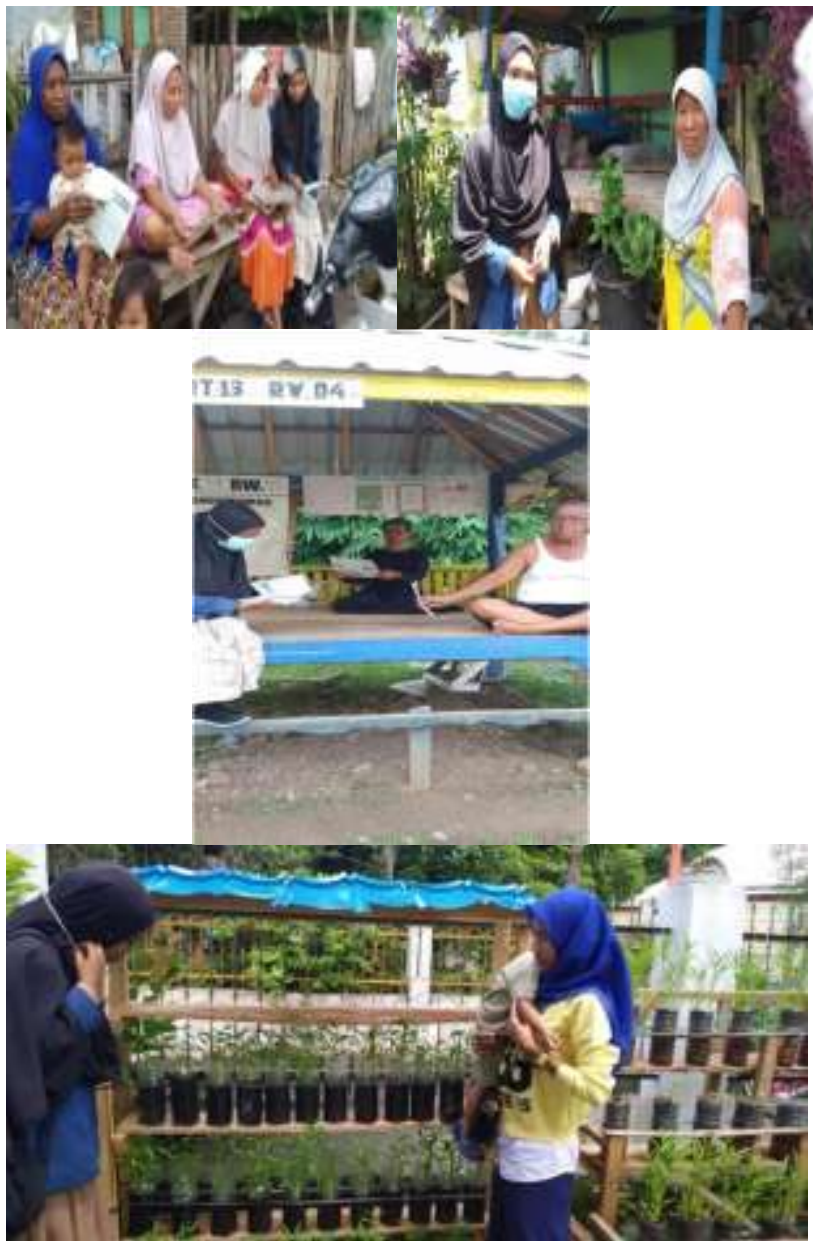

Gambar 2. Sosialisasi dan Demonstrasi Plot

\section{d. Teknik Pengumpulan Alat dan Bahan}

Metode Hidroponik Wick System, jenis sayuran pada metode ini yaitu bayam, sawi dan kangkung. Media tanam terdiri dari rockwool dan pupuk organik (nutrisi) dengan perbandingan masing - masing $10 \mathrm{ml}$ dan dimasukkan ke dalam botol bekas yang tersedia. Alat dan bahan yang digunakan:

Botol bekas

Gunting

Kain flanel

Rockwool

Air

Sutter

Nutrisi AB MIX

Bibit tanaman yang sudah dikembangkan

Saku

Kayu

Polygon

Isolasi

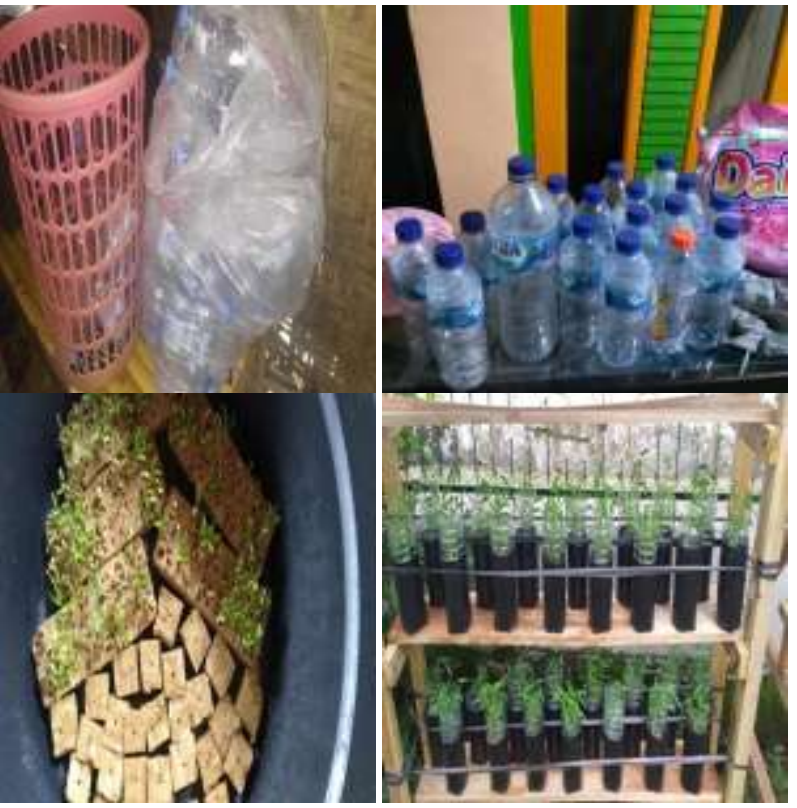

Gambar 3. Alat dan Bahan dalam Metode Hidroponik Wick System

\section{Hasil dan Pembahasan}

\section{a. Tahap Pengerjaan}

Metode Hidroponik Wick System. Sistem Wick adalah sistem yang paling sederhana dari ke 6 dasar sistem hidroponik. Ini adalah sistem pasif, yang berarti tidak ada bagian yang bergerak. Larutan nutrisi ditarik ke dalam media tumbuh dari wadah nutrisi dengan sumbu, sumbu yang digunakan adalah kain flannel yang mudah menyerap air. Media tanam yang digunakan adalah rockwool. Cara pengolahan tanaman sebagai berikut:

1. Semai bibit tanaman yang telah disiapkan, jangan lupa setelah semai tanaman harus kena sinar matahari penuh.

2. Siapkan wadah untuk tanaman, wadah yang digunakan adalah botol bekas air mineral.

3. Siapkan wadah tempat nutrisi, yaitu botol. Ukuran disesuaikan masing-masing.

4. Siapkan sumbu yang akan digunakan yaitu kain flanel.

5. Siapkan media tanam. Media tanam yang digunakan adalah rockwool.

6. Jangan lupa lubangi botol di bagian samping dan bawahnya.

7. Beli larutan nutrisi dengan membeli langsung nutrisi hidroponik $\mathrm{AB}$ Mix di toko pertanian 
terdekat Baca: nutrisi hidroponik $\mathrm{AB}$ mix, atau bisa membuat nutrisi hidoponik sendiri.

8. Pasanglah sumbu pada bagian bawah wadah, pastikan sumbu menyentuh air nutrisi hidroponik.

9. Isilah bagian bawah botol dengan tanaman yang sudah disemai dan sudah tumbuh.

10. Tanaman yang dimasukkan ke dalam botol adalah tanaman yang sudah disemai dan tumbuh selamabeberapa hari, setelah muncul daun sejati.

11.Kemudian, isikan air nutrisi yang sudah dilarutkan sesuai dengan kadar PH dan PPM tanaman yang akan ditanam secara hidroponik.

\section{b. Teknik Pengolahan}

1. Persiapan media tanam

Penggunaan media tanam dilakukan paling awal sebelum kegiatan penanaman dilakukan. Media tanam yang digunakan adalah rokwool, yang kemudian akan dimasukkan ke dalam botol yang telah didaur ulang untuk tanaman hidroponik.

\section{Pemilihan jenis tanaman}

Pemilihan jenis tanaman ini dilakukan berdasarkan keperluan dan kepentingan dari keluarga tersebut. Tanaman yang akan ditanam tentunya harus bervariasi dan bertujuan untuk dijual ke pasaran yang dapat meningkatkan pendapatan keluarga. Biasanya untuk tanaman hidoponik, yang dipilih tanaman yang cepat tumbuh dan tidak berat apabila ditanam di botol. Contoh tanamannya seperti kangkung, pakcoy, sawi dan lainnya.

\section{Pengaturan tata letak tanaman}

Tata letak tanaman ini berhubungan dengan kondisi paparan matahari. Tanaman tentunya membutuhkan sinar matahari untuk pertumbuhannya. Tata letak tanaman yang dapat dilakukan adalah dengan menyesuaikan setiap jenis tanamanan di simpan perbaris pada rakitan tempat tanaman.

\section{Kegiatan pemeliharaan}

Berbeda dengan proses berkebun secara konvensional, bercocok tanam dengan hidroponik hanya perlu penggantian larutan nutrisi secara teratur. Anda tidak perlu menyiram maupun memupuk atau melakukan penyulaman.

Pada pemberian nutrisi pertama peningkatan dosis adalah jika pertama kali menggunakan kombinasi larutan $5 \mathrm{ml}+5 \mathrm{ml}$, maka pada tahap selanjutnya bisa dinaikkan menjadi $6 \mathrm{ml}+6 \mathrm{ml}$. Namun tetap dilarutkan dengan air sebanyak 1 liter.

\section{Panen}

Tanaman sayuran seperti salada, sawi, selidri dan lainnya dapat dipanen setelah berumur 25 - 30 hari, sedangkan untuk tanaman sayuran seperti kangkung dapat dipanen setelah 30 - 40 hari setelah penanaman.

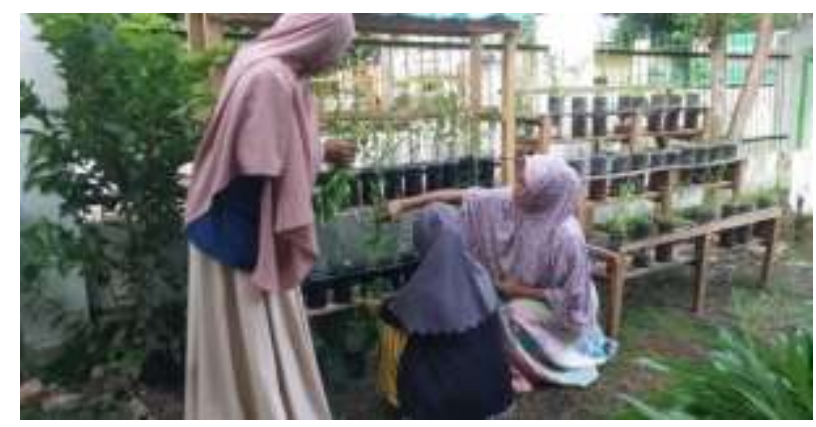

Gambar 4. Kegiatan Panen sayuran

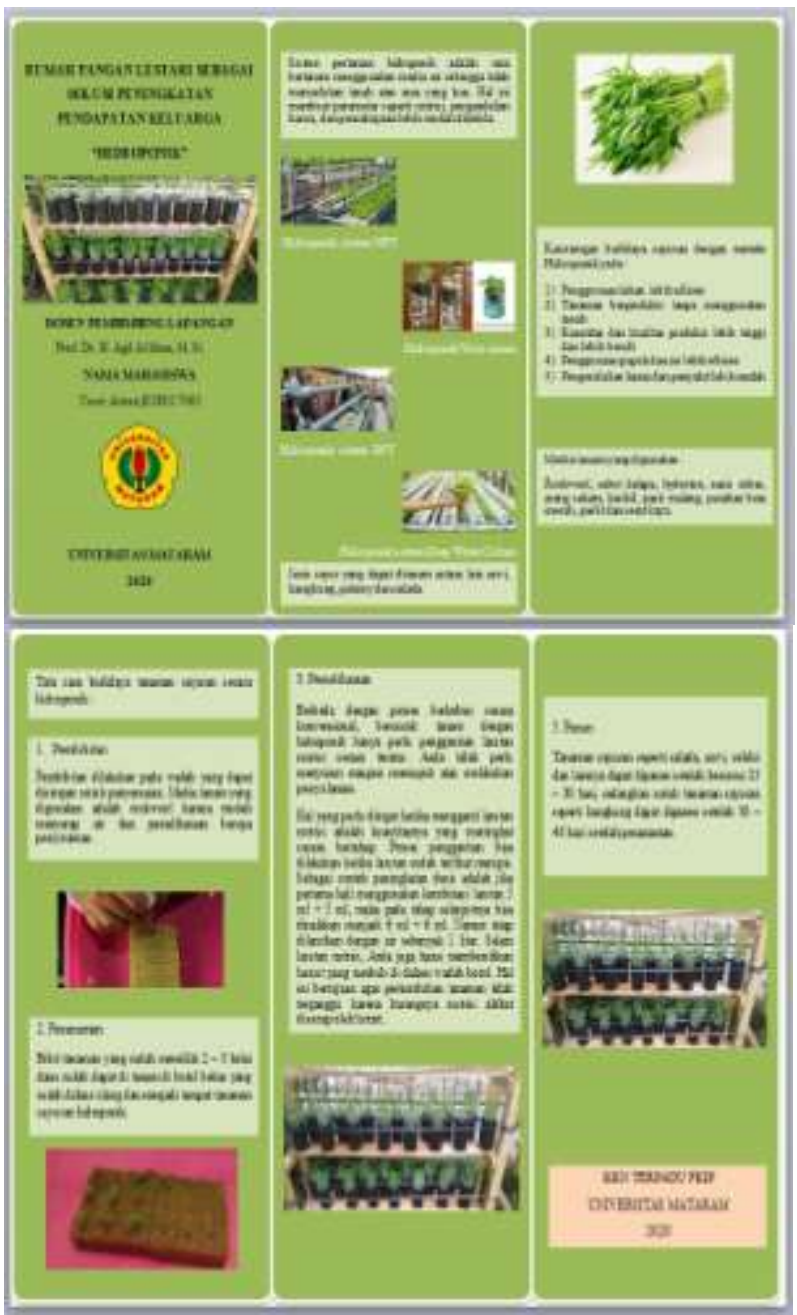

Gambar 5. Leaflet tata cara Budidaya Tanaman (Luaran) 


\section{Kesimpulan}

Partisipasi masyarakat dalam program RPL ini cukup mendapat respons positif sehingga program ini dapat berlangsung secara baik. Keberhasilan kegiatan ini dapat terlihat dari perubahan paradigm masyarakat, dimana lahan sekitar rumah yang dulunya tidak termanfaatkan kini terlihat hijau dan asri. Terjadi peningkatan pendapatan untuk memenuhi kebutuhan keluarga sehari - hari.

\section{Ucapan Terima Kasih}

Ucapan terima kasih kepada masyarakat Kelurahan sampai RT dan RW Rabadompu Barat yang telah berpartisipasi dalam melaksanakan kegiatan KKN Terpadu Era New Normal.

\section{Daftar Pustaka}

Ardli Swardana, 2020. Optimalisasi Lahan Pekarangan Sebagai Salah Satu Upaya Pencegahan Krisis Pangan di Masa Pandemi Covid-19. Program Studi Agroteknologi Fakultas Pertanian Universitas Garut.

Balitbangtan, 2011. Teknologi Kawasan Rumah Pangan Lestari (KRPL). http: //jatim. litbang.pertanian.go.id/

Dyah Pikanthi Diwanti, 2018. Pemanfaatan Pertanian Rumah Tangga (Pekarangan Rumah) dengan Tematik Budidaya Tanaman Sayuran Secara Vertikultur. Fakultas Agama Islam, Universitas Muhammadiyah Yogyakarta.

Saliem H.P., 2011. KAWASAN RUMAH PANGAN LESTARI (KRPL): Sebagai Solusi Pemantapan Ketahanan Pangan. Pusat Sosial Ekonomi dan Kebijakan Pertanian, Balitbangtan, Jakarta. 